\title{
TAKAYASU'S ARTERITIS: THE RETROSPECTIVE ANALYSIS OF PATIENTS FROM THE URAL POPULATION
}

Borodina IE ${ }^{1,2}$, Popov $A^{2}{ }^{2}$, Salavatova GG', Shardina LA²

${ }^{1}$ Sverdlovsk Regional Clinical Hospital No.1, Yekaterinburg, Russia

2 Ural State Medical University, Yekaterinburg, Russia

Takayasu's arteritis (TA) is a rare disease that can be overlooked during the first visit to a GP, rheumatologist, or any other medical specialist due to a variety of its symptoms. The aim of this study was to describe the clinical presentation and the course of patients with TA residing in the Middle Ural. A retrospective analysis was conducted using the medical records of 183 patients treated at the Sverdlovsk Regional Clinical Hospital 1 from 1979 through 2018 . The male to female ratio was 1:3. The mean age was 33.5 years for women and 35.2 for men. The most frequently involved arteries were subclavian (101 cases; $55 \%$ ), carotid (98 cases; $53 \%)$ and renal (77 cases; 42\%). Type $\vee$ was the most common angiographic type. Arterial stenosis was present in 94 (51\%) patients. Sixty-six patients received surgical interventions. Of all patients included in the analysis, 31 died. The observed 5 -year survival was $92 \%, 10$-year survival, $90 \%$ and 15 -year survival, $80 \%$. Seventy-two patients (39\%) developed major adverse cardiovascular events (MACE), including myocardial infarction, ischemic stroke, and thrombosis of large arteries/veins. The clinical presentation of TA may vary in different geographical regions.

Keywords: Takayasu's arteritis, clinical symptoms, renal artery

Author contribution: all authors participated in conceiving and planning the study, processing the data, discussing the results, and writing the manuscript. Borodina IE and Salavatova GG collected the medical records for the electronic database.

Compliance with ethical standards: the study was approved by the Ethics Committee of Ural State Medical University (Protocol No. 9 dated November 23, 2018).

Correspondence should be addressed: Irina E. Borodina

Repina 3, Yekaterinburg, Sverdlovsk region, 620014; borodysik@mail.ru

Received: 10.08.2018 Accepted: 02.03.2019 Published online: 14.03.2019

DOI: $10.24075 /$ brsmu.2019.012

\section{АРТЕРИИТ ТАКАЯСУ: РЕЗУЛЬТАТЫ РЕТРОСПЕКТИВНОГО АНАЛИЗА ПАЦИЕНТОВ УРАЛЬСКОЙ ПОПУЛЯЦИИ}

И. Э. Бородина ${ }^{1,2 凶}$, А. А. Попов², Г. Г. Салаватова'

${ }^{1}$ Свердловская областная клиническая больница № 1, Екатеринбург, Россия

2 Уральский государственный медицинский университет, Екатеринбург, Россия

Артериит Такаясу (AT) - редкое заболевание, которое ревматологи, врачи общей практики и другие специалисты могут не распознать при первичном посещении пациента из-за различных клинических проявлений. Целью исследования было оценить клиническую картину и течение АТ у 183 пациентов Среднего Урала. В ретроспективную часть исследования вошли 183 страдающих АТ пациентов, наблюдавшиеся в Свердловской областной клинической больнице № 1 в период с 1979 по 2018 г. Соотношение мужчин и женщин составляло 1 : 3. Средний возраст женщин - 33,5 года, мужчин — 35,2 лет. Наиболее часто были зарегистрированы поражения следующих артерий: подключичной - 101 (55\%) случай, сонной - 98 (53\%) случаев и почечных 77 (42\%) случаев. Наиболее часто встречался ангиографический тип V, а типичным ангиографическим признаком был артериальный стеноз — 94 (51\%). Хирургические вмешательства выполнены 66 пациентам. За период исследования зарегистрирован 31 летальный исход, пятилетняя выживаемость составила 92\%; 10-летняя - 90\%, а 15-летняя - 80\%. У 72 (39\%) пациентов развились клинически значимые сердечно-сосудистые события: инсраркт миокарда, ишемический инсульт, тромбоз крупной артерии и венозный тромбоз. В разных геограсических зонах АТ может иметь широкий спектр клинических проявлений

Ключевые слова: артериит Такаясу, клинические проявления, почечная артерия

Информация о вкладе авторов: все авторы принимали участие в планировании работы, статистической обработке, обсуждении результатов, написании и редактировании текста. И. Э. Бородина и Г. Г. Салаватова проводили сбор первичного материала и формирование электронной базы данных.

Соблюдение этических стандартов: исследование одобрено этическим комитетом ФБГОУ ВО УГМУ Министерства здравоохранения России, протокол № 9 от 23 ноября 2018 г.

$\triangle$ Для корреспонденции: Ирина Эдуардовна Бородина ул. Репина, д. 3, г. Екатеринбург, Свердловская обл., 620014; borodysik@mail.ru

Статья получена: 10.08.2018 Статья принята к печати: 02.03.2019 Опубликована онлайн: 14.03.2019

DOI: $10.24075 /$ vrgmu.2019.012

Takayasu's arteritis (TA) is a granulomatous vasculitis of the aorta and its major branches. Although TA predominantly affects Asian and South American ethnic groups, rare cases of the disease are reported in other races, too [1]. TA incidence varies from 0.8 to 2.6 cases per 1, 000, 000 adult population depending on the geographical area of residence and ethnicity [2]. At present, no epidemiological data are available on the prevalence of this disease in the Russian Federation. Because of untimely diagnosis and delayed treatment, patients with TA can develop major adverse cardiovascular events (MACE) leading to premature yet preventable death.

At its onset, TA can mimic a wide range of conditions. Specific symptoms that may not be present in the early stages include asymmetric pulse or blood pressure in the upper extremities accompanied by pronounced hypertension, impaired vision, and abdominal pain.

The aim of this retrospective study was to describe the clinical manifestations, laboratory and radiographic findings, the course and outcome of TA in 183 patients residing in the Middle Ural.

\section{METHODS}

Our retrospective cohort study included 183 patients (139 females and 44 males) with verified TA who had received treatment at Sverdlovsk Clinical Hospital No. 1 between 1979 
and 2018. The age at diagnosis was 9 to 62 years in females (mean: 33.5; median: 35; 25\%-75\% IQR: 24-43) and 12 to 59 years in male patients (mean: 35.18; median: 34; 25\%-75\% IQR: 26.5-42). The duration of the disease was 0.6 to 64 years in women (mean: 12.3 years; median: 10 years; 25\%-75\% IQR: 4-18) and 0.6 to 32 years in men (mean: 9 years; median: 7 years; 25\%-75\% IQR: 4-14.5). The time elapsed between the onset of the first clinical symptoms and the established diagnosis was 0.6-54 years in females (mean: 5.7 years; median: 3 years; $25 \%-75 \%$ IQR: $1-7$ ) and $0.6-33$ years in men (mean: 6 years; median: 4 years; 25\%-75\% IQR: 1.5-8) (Table 1).

The primary diagnosis of TA specified in the patients' medical records was verified according to the criteria proposed by the American College of Rheumatology in 1990 [3].

Following the unified protocol, we collected and analyzed demographic data, clinical, laboratory and angiography findings, and information about TA-related surgical interventions. Moriwaki's classification criteria were applied to describe arterial damage [4]. Because our retrospective study covered a long time period that had seen an evolution in clinical practices and technologies, the imaging modalities used to identify arterial stenosis, occlusion, dilation, dissection, etc. were different and included conventional catheter angiography and/or CTA and/or MRA and/or ultrasonography. Importantly, for every patient, ultrasonography findings were confirmed by at least one contrast-enhanced imaging technique.

To obtain information about the clinical manifestations and angiographic demonstration of the disease in other ethnicities, we searched the PubMed database using Takayasu's arteritis as keywords. Similar to the present study, the inclusion criteria used in the PubMed articles were based on ACR 1990 [3]. Among them were: the presence of 3 or more TA symptoms (90\% sensitivity, $97.8 \%$ specificity), including 40 years at onset, claudication (muscle weakness and pain in the extremities during movement), pulse deficit in one or both brachial arteries, blood pressure difference $>10 \mathrm{mmHg}$ in the brachial arteries,

Table 1. Characteristics of the patients with Takayasu's arteritis included in the study

\begin{tabular}{|c|c|c|c|}
\hline \multirow{2}{*}{ Characteristics } & \multicolumn{3}{|c|}{ Patients } \\
\hline & $\begin{array}{l}\text { Females } \\
139(76 \%)\end{array}$ & $\begin{array}{c}\text { Males } \\
44(24 \%)\end{array}$ & $\begin{array}{c}\text { Total } \\
n=183(100 \%)\end{array}$ \\
\hline Age at diagnosis, years, Me [25\%-75\%] & 35 [24-43] & 34 [26.5-42] & 35 [24-43] \\
\hline Duration of the disease, years, $\mathrm{Me}[25 \%-75 \%]$ & $10[4-18]$ & $7[4-14.5]$ & $13.5[6-20]$ \\
\hline Time between the onset of the first symptoms and diagnosis, Me [25\%-75\%] & $3[1-7]$ & $4[1.5-8]$ & $3[1-8]$ \\
\hline
\end{tabular}

Table 2. Clinical and laboratory findings

\begin{tabular}{|c|c|}
\hline & Patients $(n=183)$ \\
\hline Hypertension & $98(53 \%)$ \\
\hline Pain, weakness, numbness, and asymmetric pulse in the upper extremities & $89(49 \%)$ \\
\hline Malaise & $87(47.5 \%)$ \\
\hline Headache & $86(47 \%)$ \\
\hline Fever & $65(35.5 \%)$ \\
\hline Weight loss & $44(24 \%)$ \\
\hline Claudication & $40(22 \%)$ \\
\hline Dizziness & $40(2 \%)$ \\
\hline Blood pressure difference $>10 \mathrm{mmHg}$ & $37(20 \%)$ \\
\hline Chronic abdominal ischemia & $36(20 \%)$ \\
\hline Chest pain & $31(17 \%)$ \\
\hline Pain, weakness, numbness in the lower extremities & $26(14 \%)$ \\
\hline Shortness of breath & $16(8 \%)$ \\
\hline Arthralgias & $13(7 \%)$ \\
\hline \multicolumn{2}{|l|}{ Laboratory tests } \\
\hline $\mathrm{ESR}(\mathrm{mm} / \mathrm{h}), \mathrm{Me}[25 \%-75 \%]$ & $18[6-28]$ \\
\hline CRP (g/l), Me [25\%-75\%] & $0.3[0-6]$ \\
\hline WBC (10\%/l), Me [25\%-75\%] & $6.2[4-8.7]$ \\
\hline $\mathrm{Hg}(\mathrm{g} / \mathrm{l}), \mathrm{Me}[25 \%-75 \%]$ & 119 [97-128] \\
\hline \multicolumn{2}{|l|}{ TA type (Moriwaki's classification) } \\
\hline 1 & $60(33 \%)$ \\
\hline $2 a$ & $9(5 \%)$ \\
\hline $2 b$ & $1(0.5 \%)$ \\
\hline 3 & $3(2 \%)$ \\
\hline 4 & $32(17 \%)$ \\
\hline 5 & $78(43 \%)$ \\
\hline
\end{tabular}

Note: Me — median; 25\% — the lower quartile; $75 \%$ — the upper quartile. 
bruits over the subclavian arteries or abdominal aorta, and a narrowed lumen or occlusion of the aorta or its major branches in the proximal upper and lower extremities not associated with atherosclerosis, fibromuscular dysplasia and spasm.

A reference dataset was compiled from Elibrary, a free Russian academic database of research works on biomedicine and natural sciences. We ran a search using Takayasu's arteritis and TA as keywords in order to obtain information about clinical and angiographic TA manifestations in Russian patients [1, 14, 19, 20].

\section{Statistical analysis}

The data were processed in Statistica 7.0 (Statsoft inc; USA). Categorial variables were analyzed using a chi-square test. All statistical tests applied were two-tailed; differences were considered significant at $p<0.05$. The Kaplan-Meier method was used to analyze the factors affecting patients' survival. Between the groups, survival distributions were compared using the log-rank test.

\section{RESULTS}

\section{Demographic data and clinical manifestations of the disease}

At the time of examination, the most common clinical symptoms were malaise (47.5\%), elevated blood pressure (53\%), pulse asymmetry in the upper extremities (49\%), pain, weakness or numbness in the upper extremities (49\%), and headache (47\%) (Table 2).

Erythrocyte sedimentation rate (ESR), C-reactive protein (CRP) and high-sensitivity CRP were elevated (Table 2). The most common pattern of arterial involvement was Moriwaki's type $\mathrm{V}$ (the aortic arch, its major branches, the abdominal aorta and/or renal arteries).

Pathological lesions were typically found in the subclavian, carotid and renal arteries. Stenosis was the most common pathology (Table 3).

Surgical interventions were performed on 66 (36\%) patients (23 men and 43 women). Among the indications for surgery were: hemodynamically significant stenosis, occlusion or thrombosis of the involved vessels; hypertension caused by renal artery or subtotal aortic stenosis; symptoms of endstage upper/lower limb ischemia. The surgical interventions performed can be broken down into two groups: endovascular procedures (stenting, bypass grafting, angioplasty) and open reconstructive surgeries. Besides, one patient with aneurysm and thrombosis of renal arteries had to undergo nephrectomy and kidney autotransplantation (Table 4).

In the majority of cases, medication therapy included glucocorticoids (96 patients; 52\%) and antiplatelet agents, such as aspirin and dipyridamole (116 patients; 63\%) (Table 5).

Since 1979, 31 patients have died, including 18 men and 13 women. The mean age at death was 38 years in women (Me [25\%-75\%] - 36 [32-44]) and 49 years in men (Me [25\%$75 \%]-50$ [40-57]). On average, the time elapsed from the established diagnosis to the moment of death was 9.25 years (6.5 [3-16]) in men and 9 years (5 [3-10]) in women. Information about the causes of death was obtained from autopsy protocols $(n=22)$ and in conversations with the close relatives of the deceased $(n=9)$ (Table 6).

Data on the patients' survival is shown in Fig. 1. The 5-year survival rate was 92\%; 10-year survival, 90\%; and 15-year survival, 80\%. (median: 34 [20-41]).
A total of 72 patients ( 27 men and 45 women) developed cardiovascular complications. On average, age at TA onset was Me [25\%-75\%] - 33 [26-43]. TA duration before the onset of a cardiovascular even was Me [25\%-75\%] - 10 [5-20]. Age at the onset of cardiovascular complications was 38 [30-49.5] (Table 7).

\section{DISCUSSION}

In spite of being considered a rare disease, Takayasu's arteritis is studied all over the world because it poses a significant social and economic burden: patients with TA develop serious cardiovascular complications causing disabilities and premature death in young people.

Although the arsenal of available diagnostic techniques is vast, the diagnosis of TA still remains a challenge due to the variability of its symptoms and the lack of knowledge of the disease demonstrated by public health practitioners. This leads to misdiagnosis during the initial examination or delays the correct diagnosis.

Our sample of the Ural residents was dominated by women: $139(76 \%)$ of 183 participants were female. In other countries, the male to female ratio varies between $1: 2.4$ and $1: 8$ in Israel, $6.9: 1$ in Mexico and $8: 1$ in Japan [5-8]. In our study, the demographic characteristics, early clinical symptoms and the course of the disease were consistent with the previously published data indicating that TA strikes at young age [6-12].

Headache, hypertension (systolic blood pressure of $140 \mathrm{mmHg}$ and/or diastolic blood pressure of $90 \mathrm{mmHg}$ and above) were

Table 3. Arterial damage in the patients with TA (the present study)

\begin{tabular}{|c|c|}
\hline Arteries involved & $n$ \\
\hline Subclavian & $101(55 \%)$ \\
\hline Carotid & $98(53 \%)$ \\
\hline Vertebral & $16(9 \%)$ \\
\hline Axillary & $11(6 \%)$ \\
\hline Brachial & $12(6.5 \%)$ \\
\hline Pulmonary & $6(3 \%)$ \\
\hline Coronary & $31(17 \%)$ \\
\hline Celiac & $42(23 \%)$ \\
\hline Superior mesenteric & $45(25 \%)$ \\
\hline Renal & $77(42 \%)$ \\
\hline Femoral & $25(14 \%)$ \\
\hline Iliac & $33(18 \%)$ \\
\hline Aortic arch & $39(21 \%)$ \\
\hline Ascending thoracic aorta & $15(8 \%)$ \\
\hline Descending thoracic aorta & $9(5 \%)$ \\
\hline Abdominal aorta & $52(28.4 \%)$ \\
\hline Lesion types & $n$ \\
\hline Stenosis & $94(51 \%)$ \\
\hline Stenosis + occlusion & $55(30 \%)$ \\
\hline Occlusion / Aneurysm & $2(1 \%)$ \\
\hline Stenosis / aneurysm / occlusion & $7(4 \%)$ \\
\hline Occlusion & $8(4 \%)$ \\
\hline Stenosis + coarctation & $3(2 \%)$ \\
\hline Stenosis + aneurysm & $14(7.6 \%)$ \\
\hline
\end{tabular}




\section{ОРИГИНАЛЬНОЕ ИССЛЕДОВАНИЕ І КАРДИОЛОГИЯ}

Table 4. Surgical interventions performed in the patients with TA

\begin{tabular}{|c|c|}
\hline Surgery type & Patients $(n=66)$ \\
\hline Renal artery bypass with autogenous vein & $4(6 \%)$ \\
\hline Carotid-subclavian bypass grafting & $4(6 \%)$ \\
\hline Brachial artery bypass with autogenous vein & $1(1.5 \%)$ \\
\hline Autogenous vein patch reconstruction of the brachial artery & $1(1.5 \%)$ \\
\hline Renal artery stenting & $13(20 \%)$ \\
\hline Descending thoracic aorto-bifemoral bypass grafting & $3(4.5 \%)$ \\
\hline Thoracoabdominal bypass grafting & $2(3 \%)$ \\
\hline Celiac trunk and superior mesenteric artery bypass grafting & $3(4.5 \%)$ \\
\hline Abdominal aorta thrombectomy & $2(3 \%)$ \\
\hline AFBG & $7(11 \%)$ \\
\hline Renal artery angioplasty & $11(17 \%)$ \\
\hline Carotid artery stenting & $1(1.5 \%)$ \\
\hline Subclavian artery angioplasty & $1(1.5 \%)$ \\
\hline Subclavian artery stenting & $1(1.5 \%)$ \\
\hline Thrombectomy for thrombosis of a femoropopliteal bypass graft & $1(1.5 \%)$ \\
\hline $\begin{array}{l}\text { AFBG + SFA bypass grafting on the right side. Thrombosis of the aorto-femoral bypass graft/ graft thrombectomy in both branches. } \\
\text { SFA and DFA angioplasty on the left, formation of a single ostium, profundoplasty on the right side }\end{array}$ & $1(1.5 \%)$ \\
\hline Right renal artery dilatation & $2(3 \%)$ \\
\hline Kidney autotransplantation & $1(1.5 \%)$ \\
\hline Nephrectomy & $4(6 \%)$ \\
\hline Renal artery thrombectomy & $2(3 \%)$ \\
\hline BCA bypass grafting & $2(3 \%)$ \\
\hline Left renal artery endarterectomy & $1(1.5 \%)$ \\
\hline Subclavian-carotid anastomosis & $2(3 \%)$ \\
\hline Celiac artery endarterectomy & $1(1.5 \%)$ \\
\hline Brachial artery thrombectomy & $1(1.5 \%)$ \\
\hline SFA thrombectomy on the right side & $1(1.5 \%)$ \\
\hline Graft thrombectomy of the right branch & $1(1.5 \%)$ \\
\hline Transfemoral amputation & $2(3 \%)$ \\
\hline Abdominal revision for mesenteric thrombosis & $1(1.5 \%)$ \\
\hline Infrarenal aorta bypass grafting & $1(1.5 \%)$ \\
\hline Resection and end-to-end anastomosis of the small bowel following acute mesenteric thrombosis & $1(1.5 \%)$ \\
\hline Resection of aneurysm in the brachiocephalic trunk & $2(3 \%)$ \\
\hline Bifurcation alloplastic grafting of the aorta, carotid and brachiocephalic arteries & $3(4.5 \%)$ \\
\hline Carotid artery thrombectomy & $2(3 \%)$ \\
\hline Abdominal cavity and renal artery revision & $2(3 \%)$ \\
\hline $\begin{array}{l}\text { Resection of the right part of the large bowel and the terminal ileum }+ \text { jejunotransverse anastomosis } \\
\text { following acute mesenteric thrombosis }\end{array}$ & $1(1.5 \%)$ \\
\hline Iliofemoral thrombectomy & $1(1.5 \%)$ \\
\hline Implantation of arteriovenous graft in the left forearm & $1(1.5 \%)$ \\
\hline Aorto-bicarotid bypass grafting & $3(4.5 \%)$ \\
\hline Thoracoabdominal replacement following aortic coarctation & $1(1.5 \%)$ \\
\hline Aneurysm resection in the abdominal aorta & $1(1.5 \%)$ \\
\hline Aortic stenting following coarctation & $1(1.5 \%)$ \\
\hline Resection of proximal anastomotic aneurysm in the subclavian artery & $1(1.5 \%)$ \\
\hline Carotid-subclavian bypass grafting & $1(1.5 \%)$ \\
\hline Autogenous vein repair of the subclavian artery & $1(1.5 \%)$ \\
\hline Brachial artery dilatation & $1(1.5 \%)$ \\
\hline Iliofemoral bypass grafting & $1(1.5 \%)$ \\
\hline Coronary artery stenting & $5(7.5 \%)$ \\
\hline AMCB & $1(1.5 \%)$ \\
\hline DFA stenting on the right & $1(1.5 \%)$ \\
\hline Linear iliofemoral bypass on the right side & $1(1.5 \%)$ \\
\hline
\end{tabular}

Note: AFBG — aorto-femoral bypass grafting; AMCB — aorto- and mammary coronary bypass; BCA — brachiocephalic artery; SFA — superficial femoral artery; DFA - deep femoral artery. 
Table 5. Medication therapy received by the patients with Takayasu arteriitis

\begin{tabular}{|c|c|}
\hline Medication therapy & Patients $(n=183)$ \\
\hline Glucocorticoids & $96(52 \%)$ \\
\hline Glucocorticoids + immunosuppressive agents (cyclophosphamide, azathioprine, hydroxychloroquine, methotrexate) & $43(23 \%)$ \\
\hline No immunosuppressive therapy received or no exhaustive information about immunosuppressive therapy available in the medical records & $40(21 \%)$ \\
\hline Genetically engineered drugs & $0(0 \%)$ \\
\hline Antiplatelet agents & $116(63 \%)$ \\
\hline Statins & $27(15 \%)$ \\
\hline Nonsteroidal anti-inflammatory drugs & 42 (23\%) \\
\hline Plasmapheresis & 31 (17\%) \\
\hline
\end{tabular}

Table 6. Causes of death in the patients with TA

\begin{tabular}{|c|c|}
\hline Cause of death & Patients $(n=31)$ \\
\hline Multiple cerebral infarctions resulting from progressive cerebral ischemia & $1(3 \%)$ \\
\hline Cerebral infarction due to thrombosis of the internal carotid artery & $1(3 \%)$ \\
\hline Bronchopneumonia & $1(3 \%)$ \\
\hline Decompensated heart failure resulting from aortic regurgitation & $2(6 \%)$ \\
\hline Massive bleeding due to anastomotic suture line failure following autogenous vein replacement of the renal artery & $1(3 \%)$ \\
\hline $\begin{array}{l}\text { Bronchopneumonia complicated by abscess after aorto-bicarotid bypass grafting, cerebral reperfusion injury and postoperative coma } \\
\text { following implantation of a cardiac pacemaker }\end{array}$ & $1(3 \%)$ \\
\hline $\begin{array}{l}\text { Cerebral infarction + encephalopathy after cerebral reperfusion injury and postoperative cerebral } \\
\text { coma after aorto-bicarotid bypass grafting }\end{array}$ & $1(3 \%)$ \\
\hline Postoperative sepsis caused by suppurative mediastinitis after performing subclavian-carotid anastomosis & $1(3 \%)$ \\
\hline Cerebral infarction due to thromboembolism following resection of brachiocephalic aneurysm & $1(3 \%)$ \\
\hline Cerebral infarctions in the presence of progressive cerebral ischemia after bifurcation aorto-carotid bypass grafting & $1(3 \%)$ \\
\hline Small bowel gangrene in the presence of intestinal ischemia after bifurcation aorto-femoral bypass grafting & $1(3 \%)$ \\
\hline Postoperative peritonitis due to anastomotic suture line failure following small bowel resection for mesenteric thrombosis & $2(6 \%)$ \\
\hline Intracerebral hemorrhage due to hypertension & $2(6 \%)$ \\
\hline Pulmonary embolism caused by deep vein thrombosis of the lower extremities & $1(3 \%)$ \\
\hline Pulmonary embolism caused by multiple arterial and venous thrombosis of the internal organs & $1(3 \%)$ \\
\hline Cerebral infarction of the common carotid artery & $1(3 \%)$ \\
\hline Massive bleeding due to the rupture of dissecting aortic arch aneurysm & $1(3 \%)$ \\
\hline Massive bleeding due to the rupture of dissecting abdominal aortic aneurysm & $2(6 \%)$ \\
\hline Acute renal failure caused by abdominal aorta thrombosis & $1(3 \%)$ \\
\hline Peritonitis due to acute mesenteric thrombosis & $1(3 \%)$ \\
\hline Myocardial infarction & $2(6 \%)$ \\
\hline Hepatic cancer & $1(3 \%)$ \\
\hline Myocardial insufficiency (ischemic stroke) & $1(3 \%)$ \\
\hline Poisoning & $2(6 \%)$ \\
\hline Unknown & $2(6 \%)$ \\
\hline
\end{tabular}

Note: PE - pulmonary embolism.

similarly frequent in all studies including our cohort of patients [9-14] (Table 8).

The most commonly involved vessels were the subclavian, carotid and renal arteries. Stenosis was the most common lesion type. The most prevalent (43\%) TA type was type $V$ (according to Moriwaki's classification). The carotid and subclavian arteries suffered the same types of lesions in all analyzed studies, including ours. Similar to other cohorts, the Ural sample demonstrated rare involvement of the vertebral, pulmonary and iliac arteries. Interestingly, damage to the ascending aorta and coronary arteries was very frequent in the Korean population [9,15-18] (Table 9).
There are reports that the brachiocephalic artery is affected in $85 \%$ of Russian patients with TA, whereas damage to the renal artery is observed in $23 \%$ cases $[19,20]$ (Table 10).

Except for the Serbian study, all other research works indicate that type $\mathrm{V}$ of arterial involvement is the most frequent, while type III is the most rare. The Serbian sample is characterized by a high frequency of types I and lla damage. Type Illb prevails in the Korean population. Type IV is relatively widespread in India and Brazil. Both genetic and environmental factors can contribute to the clinical manifestations of TA (Table 11) [15-17, 21-24]. 


\section{ОРИГИНАЛЬНОЕ ИССЛЕДОВАНИЕ І КАРДИОЛОГИЯ}

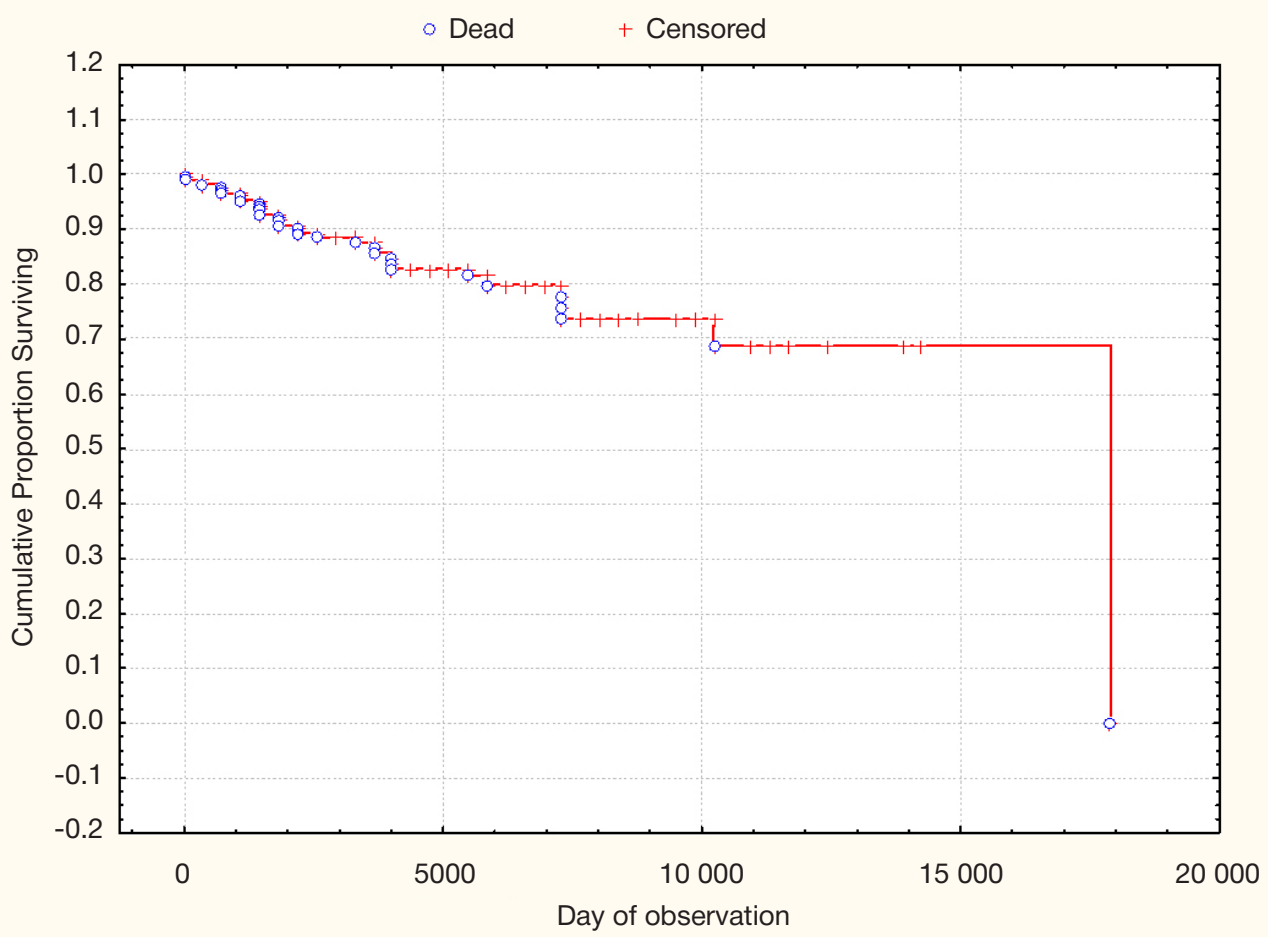

Fig. 1. Survival of the patients with TA

Table 7. Cardiovascular complications in patients with TA

\begin{tabular}{|c|c|}
\hline & Patients with MACE $(n=72)$ \\
\hline Myocardial infarction & $14(20 \%)$ \\
\hline Ischemic stroke & $24(35 \%)$ \\
\hline Transient ischemic attack & $3(3 \%)$ \\
\hline Hemorrhagic stroke & $4(6 \%)$ \\
\hline Thrombosis of the renal artery & $5(7 \%)$ \\
\hline Thrombosis of the brachial artery & $2(3 \%)$ \\
\hline Mesenteric thrombosis & $4(6 \%)$ \\
\hline Thrombosis of the radial artery & $1(1.4 \%)$ \\
\hline Thrombosis of the brachiocephalic trunk & $1(1.4 \%)$ \\
\hline Thrombosis of the dorsalis pedis artery & $2(3 \%)$ \\
\hline Thrombosis of the axillary artery & $1(1.4 \%)$ \\
\hline Thrombosis of the infrarenal aorta & $1(1.4 \%)$ \\
\hline Thrombosis of the abdominal artery & $2(3 \%)$ \\
\hline Thrombosis of the carotid artery & $3(3 \%)$ \\
\hline Thrombosis of the subclavian artery & $3(3 \%)$ \\
\hline Celiac thrombosis & $1(1.4 \%)$ \\
\hline Aneurysm rupture in the thoracic aorta & $2(3 \%)$ \\
\hline Aneurysm rupture in the abdominal aorta & $1(1.4 \%)$ \\
\hline Thrombosis of the aorto-femoral bypass graft & $6(8 \%)$ \\
\hline PE & $3(3 \%)$ \\
\hline Thrombosis of the jugular vein & $2(3 \%)$ \\
\hline Cerebral venous sinus thrombosis & $1(1.4 \%)$ \\
\hline Thrombosis of the sural veins & $1(1.4 \%)$ \\
\hline Thrombosis of the small saphenous vein & $1(1.4 \%)$ \\
\hline Thrombophlebitis of the tibial veins & $1(1.4 \%)$ \\
\hline Thrombophlebitis of the aorto-venous bypass graft of the renal artery & $1(1.4 \%)$ \\
\hline
\end{tabular}


Table 8. Clinical symptoms of TA in different geographical regions

\begin{tabular}{|c|c|c|c|c|c|c|c|}
\hline & $\begin{array}{l}\text { This study } \\
(n=183), \%\end{array}$ & $\begin{array}{c}\text { Italy } \\
(n=67), \% \\
{[9]}\end{array}$ & $\begin{array}{c}\text { India } \\
(n=106), \% \\
{[10]}\end{array}$ & $\begin{array}{c}\text { Brazil } \\
(n=73), \% \\
{[11]}\end{array}$ & $\begin{array}{l}\text { South Africa } \\
(n=272), \% \\
{[12]}\end{array}$ & $\begin{array}{c}\text { Japan } \\
(n=84), \% \\
{[13]}\end{array}$ & $\begin{array}{c}\text { Russia } \\
(n=215), \% \\
{[14]}\end{array}$ \\
\hline Malaise & 47.5 & $\mathrm{n} / \mathrm{a}$ & $\mathrm{n} / \mathrm{a}$ & $\mathrm{n} / \mathrm{a}$ & 10 & $\mathrm{n} / \mathrm{a}$ & 50 \\
\hline Weight loss & 24 & 12 & 9.4 & 28 & $\mathrm{n} / \mathrm{a}$ & 5 & 9 \\
\hline Fever & 35.5 & 39 & 16 & 26 & 10 & 20 & $n / a$ \\
\hline Headache & 47 & 33 & 47 & 45 & $n / a$ & $n / a$ & 50 \\
\hline Dizziness & 22 & 27 & $n / a$ & 29 & $n / a$ & $\mathrm{n} / \mathrm{a}$ & $n / a$ \\
\hline $\begin{array}{l}\text { Pain, weakness, numbness } \\
\text { of the upper extremities }\end{array}$ & 49 & 52 & 59 & 58 & 12 & 54 & 50 \\
\hline $\begin{array}{l}\text { Hypertension (systolic pressure } \\
\text { of } 140 \mathrm{mmHg} \text { and diastolic pressure } \\
\text { of } 90 \mathrm{mmHg} \text { ) }\end{array}$ & 53 & 46 & 52 & 36 & 77 & 52 & 68 \\
\hline $\begin{array}{l}\text { Pulse asymmetry in the upper } \\
\text { extremities }\end{array}$ & 49 & 73 & 59 & 85 & 12 & 54 & 50 \\
\hline Blood pressure difference $>10 \mathrm{mmHg}$ & 20 & 72 & 59 & 85 & 12 & 54 & 50 \\
\hline
\end{tabular}

Table 9. Arteries affected by the pathology in patients with TA residing in different geographical regions

\begin{tabular}{|c|c|c|c|c|c|c|}
\hline Arteries & $\begin{array}{l}\text { This study } \\
(n=183), \%\end{array}$ & $\begin{array}{c}\text { China } \\
(n=411), \% \\
{[15]}\end{array}$ & $\begin{array}{c}\text { Korea } \\
(n=20), \% \\
{[16]}\end{array}$ & $\begin{array}{c}\text { USA } \\
(n=126), \% \\
{[17]}\end{array}$ & $\begin{array}{c}\text { Italy } \\
(n=104), \% \\
{[9]}\end{array}$ & $\begin{array}{c}\text { France } \\
(n=82), \% \\
{[18]}\end{array}$ \\
\hline Subclavian & 53 & 79.8 & 67.1 & 6.3 & 65.6 & 68.3 \\
\hline Carotid & 55 & 79.1 & 72.1 & 50.9 & 44.3 & 59.8 \\
\hline Vertebral & 9 & 28.7 & $n / a$ & 18.5 & 13 & 28.0 \\
\hline Pulmonary & 3 & 68.9 & 13.4 & 33.3 & $\mathrm{n} / \mathrm{a}$ & $n / a$ \\
\hline Coronary & 17 & 35.7 & 63.3 & 22.2 & $\mathrm{n} / \mathrm{a}$ & $\mathrm{n} / \mathrm{a}$ \\
\hline Mesenteric & 25 & 29.7 & 22.8 & 24.7 & 31.6 & $n / a$ \\
\hline Renal & 42 & 48.9 & 32.2 & 18.7 & 34.4 & 14.6 \\
\hline Iliac & 18 & 27.2 & 13.3 & 13.5 & 19.7 & 18.3 \\
\hline Ascending aorta & 8 & 9.5 & 47.8 & 9.1 & $\mathrm{n} / \mathrm{a}$ & $\mathrm{n} / \mathrm{a}$ \\
\hline
\end{tabular}

Table 10. Damage to the arteries in patients with TA representing the Russian population

\begin{tabular}{|c|c|c|c|}
\hline Arteries & This study $(n=183)$ & Central Russian regions [19] & North European Russia [20] \\
\hline Subclavian & 55 & \multirow{3}{*}{$85 \%$} & $\mathrm{n} / \mathrm{a}$ \\
\hline Carotid & 53 & & $\mathrm{n} / \mathrm{a}$ \\
\hline Vertebral & 9 & & $\mathrm{n} / \mathrm{a}$ \\
\hline Pulmonary & 3 & $\mathrm{n} / \mathrm{a}$ & $\mathrm{n} / \mathrm{a}$ \\
\hline Coronary & 17 & $\mathrm{n} / \mathrm{a}$ & $\mathrm{n} / \mathrm{a}$ \\
\hline Mesenteric & 25 & $\mathrm{n} / \mathrm{a}$ & $\mathrm{n} / \mathrm{a}$ \\
\hline Renal & 42 & $\mathrm{n} / \mathrm{a}$ & $23 \%$ \\
\hline Iliac & 18 & $\mathrm{n} / \mathrm{a}$ & $\mathrm{n} / \mathrm{a}$ \\
\hline Ascending aorta & 5 & $\mathrm{n} / \mathrm{a}$ & $\mathrm{n} / \mathrm{a}$ \\
\hline
\end{tabular}

Table 11. Angiographic characteristics of TA in different regions across the world

\begin{tabular}{|c|c|c|c|c|c|c|c|c|}
\hline & This study & China [15] & Korea [16] & USA[17] & India [21] & Mexico [22] & Serbia [23] & Brazil [24] \\
\hline Type I, \% & 33 & 22.1 & 11.1 & 20 & 6.9 & 19 & 50 & 11.9 \\
\hline Type Ila, \% & 5 & 3.9 & 8.6 & 6 & 1 & 3 & 19 & 6 \\
\hline Type Ilb, \% & 0,5 & 3.9 & 14.1 & 7 & 5.9 & 4 & 0 & 1 \\
\hline Type III, \% & 2 & 2.9 & 4.0 & 5 & 2.9 & 4 & 0 & 9 \\
\hline Type IV, \% & 17 & 6.3 & 7.6 & 5 & 28.4 & 2 & 0 & 27 \\
\hline Type V, \% & 43 & 60.8 & 54.5 & 57 & 54.9 & 69 & 31 & 18 \\
\hline
\end{tabular}


In our cohort of patients, survival rates were similar to those reported in previous publications [17, 25-27]. However, there are reports of different 5- and 10-year survival rates (69 and $36 \%$, respectively) [28]. In the Arab population, the 5-year survival rate is as low as 50\% [29]. The record-breaking 100\% survival rate is reported in Japan [30].

A national TA registry is needed to estimate the prevalence of the disease in different ethnic groups. It will provide valuable information about TA presentation and clinical course necessary to establish the timely diagnosis. The actual prevalence of TA can be higher than suggested in the literature. Timely diagnosis and treatment will help to improve patient outcomes.

The main limitation of the present study is its retrospective design. Besides, the study was conducted in inpatients only. In different time periods, the diagnostic procedures used in the patients were different, which also complicates data interpretation.

\section{CONCLUSIONS}

The clinical presentations of TA are diverse. Timely diagnosis can be a challenge when a patient presenting with general inflammation has a healthy pulse pattern, develops collateral circulation and demonstrates no specific symptoms of arterial damage. Patients with TA should be warned against a high risk of cardiovascular complications and advised to monitor and control their blood pressure, lipid counts and blood coagulability. Hemodynamically significant stenosis, occlusion or thrombosis of damaged arteries can be corrected surgically, contributing to antihypertensive therapy, helping to eliminate the symptoms of ischemia and prevent new vascular complications. The majority of patients in our cohort had Moriwaki's type $\mathrm{V}$ of arterial damage. High survival rates can be explained by a young age and a capacity to develop collateral circulation.

\section{References}

1. Nasonov EL, Nasonova VA. Rheumatology. National guidelines Moscow, 2010; 539-67.

2. Volosnyakov D, Glazyrina G, Serebryakova E, et al. Nonspecific aortoarteritis (Takayasu arteritis) in children and adolescents: literature review and clinical case. Difficult patient. 2015; 1 (13): 36-9.

3. Arend W, Michel B, Bloch D, et al. The American College of Rheumatology 1990 criteria for the classification of Takayasu arteritis. Arthritis Rheum. 1990; (33): 1129-34.

4. Moriwaki R, Noda M, Yajima M, et al. Clinical manifestations of Takayasu arteritis in India and Japan new classification of angiographic findings. Angiology. 1997; (48): 369-79.

5. Asri A, Tazi-Mezalek Z, Aouni M, et al. Takayasu's disease in Morocco. Report of 47 cases. Rev Med Interne. 2002; (23): 9-20.

6. Ishikawa K, Maetani S. Long-term outcome for 120 Japanese patients with Takayasu's disease. Clinical and statistical analyses of related prognostic factors. Circulation. 1994; (90): 1855-60.

7. Toshihiko N. Current status of large and small vessel vasculitis in Japan. Int J Cardiol. 1996; (54): 91-8.

8. Zheng DY, Liu LS, Fan DJ. Clinical studies in 500 patients with aortoarteritis. Chin Med J. 1990; (103): 536-40.

9. Vanoli $M$, Bacchiani $G$, Origgi L, et al. Takayasu's arteritis: a changing disease. J Nephrol. 2001; (14): 497-505.

10. Jain S, Kumari S, Ganguly N, et al. Current status of Takayasu arteritis in India. Int J Cardiol. 1996; (54): 111-6.

11. Sato EL, Hatta FS, Levy-Neto M, et al. Demographic, clinical, and angiographic data of patients with Takayasu arteritis in Brazil. Int $\mathrm{J}$ Cardiol. 1998; (66): 67-70.

12. Mwipatayi B, Jeffeiy P. Takayasu arteritis: clinical features and management: report of 272 cases. ANZ J Surg. 2005; (75): 110-7.

13. Nakao K, Ikeda M, et al. Takayasu's arteritis: Clinical Report of Eighty-four Cases and Immunological Studies of Seven Cases. Circulation. 1967; (35): 1141-55.

14. Arabidze G, Abugova SP, et al. Clinical aspects of Takayasu syndrome (215 cases). Ter Arkh. 1980; 52 (5): 124-9.

15. Jing Li, Fei Sun, et al. The clinical characteristics of Chinese TAayasu's arteritis patients: a retrospective study of 411 patients over 24 years. Arthritis Res Ther. 2017; (19): 107. DOI: 10.1186/ s13075-017-1307-z.

16. Lee GY, Jang SY, Ko SM, et al. Cardiovascular manifestations of TAayasu arteritis and their relationship to the disease activity: analysis of 204 Korean patients at a single center. Int $\mathrm{J}$ Cardiol. 2012; 159 (1): 14-20.

17. Schmidt J, Kermani TA, Bacani AK, et al. Diagnostic features,

treatment, and outcomes of Takayasu arteritis in a US cohort of 126 patients. Mayo Clin Proc. 2013; 88 (2): 821-30.

18. Arnaud L, Haroche J, Toledano D, et al. Cluster analysis of arterial involvement in Takayasu arteritis reveals symmetric extension of the lesions in paired arterial beds. Arthritis Rheum. 2011; 63 (4): 1136-40.

19. Pokrovskij AV, Zotikov AE, Yudin VI. Nespecificheskij aortoarteriit (bolezn' Takayasu). M.: IRIS, 2002.

20. Chikhladze NM. Arterial hypertension in patients with non-specific aortoarteritis. Systemic Hypertension. 2018; 15 (2): 43-48. DOI: 10.26442/2075-082X_2018.2.43-48.

21. Moriwaki R, Noda M, Yajima $M$, et al. Clinical manifestations of Takayasu arteritis in India and Japan-new classification of angiographic findings. Angiology. 1997; 48 (5): 369-79.

22. Soto ME, Espinola N, Flores-Suarez LF, et al. Takayasu arteritis: clinical features in 110 Mexican Mestizo patients and cardiovascular impact on survival and prognosis. Clin Exp Rheumatol. 2008; 26 (3 Suppl 49): 9-15.

23. Petrovic-Rackov L, Pejnovic N, Jevtic $M$, et al. Longitudinal study of 16 patients with Takayasu's arteritis: clinical features and therapeutic management. Clin Rheumatol. 2009 Feb; 28 (2): 179-85. DOI: 10.1007/s10067-008-1009-7.

24. Clemente Maria, et al. Brazilian multicenter study of 71 patients with juvenile-onset TAayasu's arteritis: clinical and angiographic features. Rev Brasil Reumatol. 2016 Mar; 56 (2): 145-51.

25. Phillip R, Luqmani R. Mortality in systemic vasculitis: a systemic review. Clin Exp Rheumatol. 2008; 26 (5): 94-104.

26. Balakrishnan $K G$, Subramanyan R, Joy J. Natural history of aortoarteritis (Takayasu's disease). Circulation.1989; 80 (3): 429-37.

27. Hall S, Barr W, Lie JT, Stanson AW, Kazmier FJ, Hunder GG. Takayasu arteritis. A study of 32 North American patients. Medicine (Baltimore). 1985; 64 (2): 89-99.

28. Park MC, Lee SW, Park YB, Chung NS. Clinical characteristics and outcomes of Takayasus arteritis: analysis of 108 patients using standardized criteria for diagnosis, activity assessment and angiographic classification. Lee Scand J Rheumatol. 2005; 34 (4): 284-92.

29. Mustafa K. Takayasu's arteritis in Arabs. Clin Rheumatol. 2014 Dec; 33 (12): 1777-83. DOI: 10.1007/s10067-014-2633-z.

30. Ishihara T, Haraguchi G, Kamiishi T, Tezuka D, Inagaki H, Isobe M. Sensitive assessment of activity of Takayasu's arteritis by pentraxin3, a new biomarker. J Am Coll Cardiol. 2011; 57 (16): 1712-3. 


\section{Литература}

1. Насонов Е. Л. Ревматология: российские клинические рекомендации. М.: ГЕОТАР-Медиа, 2010; 331 с.

2. Волосников Д. К., Глазырина Г. А., Серебрякова Е. Н. Неспецисический аортоартериит (артериит Такаясу) у детей и подростков: обзор литературы и описание случая. Трудный пациент. 2015; 1 (13): 36-9.

3. Arend W, Michel B, Bloch D, et al. The American College of Rheumatology 1990 criteria for the classification of Takayasu arteritis. Arthritis Rheum. 1990; (33): 1129-34.

4. Moriwaki R, Noda M, Yajima M, et al. Clinical manifestations of Takayasu arteritis in India and Japan new classification of angiographic findings. Angiology. 1997; (48): 369-79.

5. Asri A, Tazi-Mezalek Z, Aouni M, et al. Takayasu's disease in Morocco. Report of 47 cases. Rev Med Interne. 2002; (23): 9-20.

6. Ishikawa K, Maetani S. Long-term outcome for 120 Japanese patients with Takayasu's disease. Clinical and statistical analyses of related prognostic factors. Circulation. 1994; (90): 1855-60.

7. Toshihiko N. Current status of large and small vessel vasculitis in Japan. Int J Cardiol. 1996; (54): 91-8.

8. Zheng DY, Liu LS, Fan DJ. Clinical studies in 500 patients with aortoarteritis. Chin Med J. 1990; (103): 536-40.

9. Vanoli M, Bacchiani G, Origgi L, et al. Takayasu's arteritis: a changing disease. J Nephrol. 2001; (14): 497-505.

10. Jain S, Kumari S, Ganguly N, et al. Current status of Takayasu arteritis in India. Int J Cardiol. 1996; (54): 111-6.

11. Sato EL, Hatta FS, Levy-Neto M, et al. Demographic, clinical, and angiographic data of patients with Takayasu arteritis in Brazil. Int $J$ Cardiol. 1998; (66): 67-70.

12. Mwipatayi B, Jeffeiy P. Takayasu arteritis: clinical features and management: report of 272 cases. ANZ J Surg. 2005; (75): 110-7.

13. Nakao K, Ikeda M, et al. Takayasu's arteritis: Clinical Report of Eighty-four Cases and Immunological Studies of Seven Cases. Circulation. 1967; (35): 1141-55.

14. Арабидзе Г. Г., Абугова С. П., Матвеева Л. С. Клинические аспекты болезни Такаясу (215 наблюдений). Тер. архив. 1980; (5): 124-9

15. Jing Li, Fei Sun, et al. The clinical characteristics of Chinese TAayasu's arteritis patients: a retrospective study of 411 patients over 24 years. Arthritis Res Ther. 2017; (19): 107. DOI: 10.1186/ s13075-017-1307-z

16. Lee GY, Jang SY, Ko SM, et al. Cardiovascular manifestations of TAayasu arteritis and their relationship to the disease activity: analysis of 204 Korean patients at a single center. Int J Cardiol. 2012; 159 (1): 14-20.
17. Schmidt J, Kermani TA, Bacani AK, et al. Diagnostic features, treatment, and outcomes of Takayasu arteritis in a US cohort of 126 patients. Mayo Clin Proc. 2013; 88 (2): 821-30.

18. Arnaud L, Haroche J, Toledano D, et al. Cluster analysis of arterial involvement in Takayasu arteritis reveals symmetric extension of the lesions in paired arterial beds. Arthritis Rheum. 2011; 63 (4): 1136-40.

19. Покровский А. В., Зотиков А. Е., Юдин В. И. Неспецифический аортоартериит (болезнь Такаясу). М.: ИРСИСъ, 2002.

20. Чихладзе Н. М. Артериальная гипертензия у больных с неспецифическим аортоартериитом. Системные гипертензии. 2018; 15 (2): 43-8.

21. Moriwaki R, Noda M, Yajima $M$, et al. Clinical manifestations of Takayasu arteritis in India and Japan - new classification of angiographic findings. Angiology. 1997; 48 (5): 369-79.

22. Soto ME, Espinola N, Flores-Suarez LF, et al. Takayasu arteritis: clinical features in 110 Mexican Mestizo patients and cardiovascular impact on survival and prognosis. Clin Exp Rheumatol. 2008; 26 (3 Suppl 49): 9-15.

23. Petrovic-Rackov L, Pejnovic N, Jevtic M, et al. Longitudinal study of 16 patients with Takayasu's arteritis: clinical features and therapeutic management. Clin Rheumatol. 2009 Feb; 28 (2): 179-85. DOI: 10.1007/s10067-008-1009-7.

24. Clemente Maria, et al. Brazilian multicenter study of 71 patients with juvenile-onset TAayasu's arteritis: clinical and angiographic features. Rev Brasil Reumatol. 2016 Mar; 56 (2): 145-51.

25. Phillip R, Luqmani R. Mortality in systemic vasculitis: a systemic review. Clin Exp Rheumatol. 2008; 26 (5): 94-104.

26. Balakrishnan KG, Subramanyan R, Joy J. Natural history of aortoarteritis (Takayasu's disease). Circulation. 1989; 80 (3): 429-37.

27. Hall S, Barr W, Lie JT, Stanson AW, Kazmier FJ, Hunder GG. Takayasu arteritis. A study of 32 North American patients. Medicine (Baltimore). 1985; 64 (2): 89-99.

28. Park MC, Lee SW, Park YB, Chung NS. Clinical characteristics and outcomes of Takayasus arteritis: analysis of 108 patients using standardized criteria for diagnosis, activity assessment and angiographic classification. Lee Scand J Rheumatol. 2005; 34 (4): 284-92.

29. Mustafa K. Takayasu's arteritis in Arabs. Clin Rheumatol. 2014 Dec; 33 (12): 1777-83. DOI: 10.1007/s10067-014-2633-z.

30. Ishihara T, Haraguchi G, Kamiishi T, Tezuka D, Inagaki H, Isobe M. Sensitive assessment of activity of Takayasu's arteritis by pentraxin3, a new biomarker. J Am Coll Cardiol. 2011; 57 (16): 1712-3. 